\title{
Axial capacity of steel built-up battened columns
}

\author{
P. Pieczka \& P. Iwicki \\ Department of Metal Structures, Faculty of Civil and Environmental Engineering, Gdańsk University of \\ Technology, Gdańsk, Poland
}

\begin{abstract}
This paper deals with the numerical investigation aimed to study the axial capacity of pin-ended steel built-up columns. Three methods of calculating forces in chords and batten, taking into account the material and geometric imperfections specified in the Eurocode 3 are considered. The aim of this study was to compare different methods allowing the calculation of the column load capacity and determine a simpler and faster method than the present Eurocode 3 procedure related to design of built up members. In the paper, the method according to Eurocode 3 for uniform built-up compression member and the method according to PN-B-03200:1990 are compared with the code method for the structure modeled as separate members for column chords and battens. Calculations were carried out for the column modeled by 1D-beam elements and for a whole shell model of the column. Finite element (FE) models were established and verified against the built-up columns with similar configurations that were tested experimentally in the studies presented in the literature, and then compared with the calculations specified in Eurocode 3.
\end{abstract}

\section{INTRODUCTION}

Thanks to the spacing of the chords, built-up columns make it possible to obtain high moments of inertia at low cross-sectional area, and thus low steel expenditure. This is especially important for columns with long buckling length. The chords can be made of hot-rolled or cold-formed sections, connections between them can be made with lacings or battens.

The most common in engineering practice method of calculation of built-up columns with battens is the procedure according to Eurocode 3 (2005) (EC3) where the model of a uniform built-up compression member is applied. The assumption described in EC3 allows to calculate regular structures with battens smeared along the column. The problem is that this method is precisely defined only for columns with parallel chords of constant cross-section, modular battens distribution and pinned supports.

\section{STATIC ANALYSIS}

The load capacity of the entire built-up member can be calculated knowing the values of internal forces in its individual elements, and then checking the code limit load for each element separately. The EC3 standard recommends assuming an initial bow imperfection $e_{0}=L /$ 500 , where $L$ is the column length. The calculation of internal forces with initial imperfection can be performed in several ways, three of them are presented below.

For the calculation of internal forces, the data of an example column were adopted. Steel S235 (yield stress $f_{y}=235 \mathrm{MPa}$, elastic modulus $E=210 \mathrm{GPa}$ ) was used, and the column was loaded with a concentrated force of $1500 \mathrm{kN}$. Figure 1 shows the diagram and dimensions of the built-up member. 

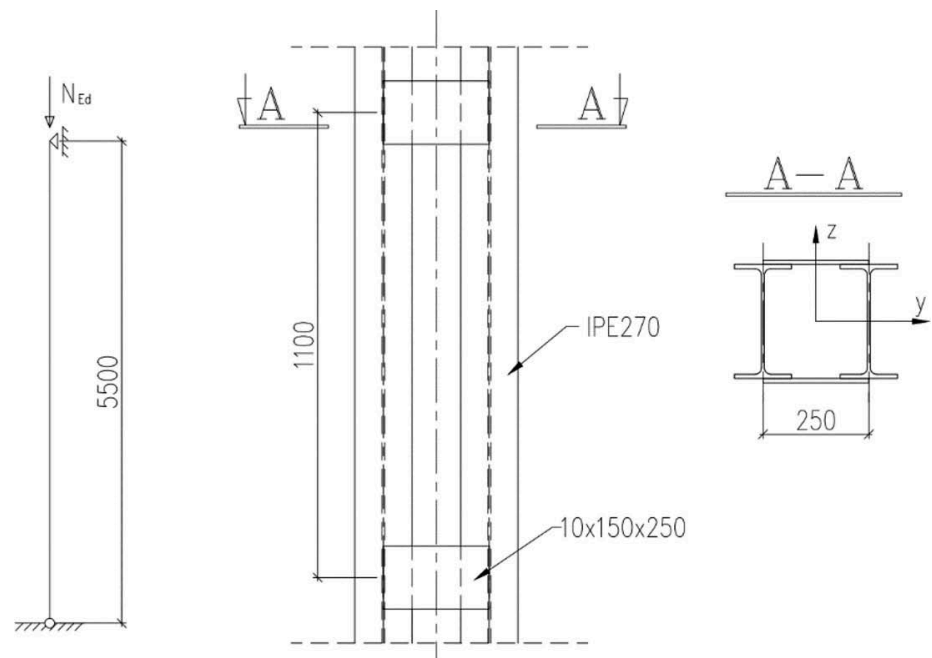

Figure 1. Diagram and dimensions of the built-up member of the example.

\section{$2.1 \quad$ Procedure according to Eurocode 3 (EC3)}

PN-EN 1993-1-1, point 6.4 describes the method of calculating internal forces in the chords and battens of built-up members with parallel and constant chords along the entire length of the column, and the battens fixed in the modular arrangement (not less than 4 battens). The supports of the column must be pinned. For columns with a different boundary condition or variable cross-section, EC3 recommends performing appropriate modifications, but it has not been specified how to implement them.

The distribution of internal forces in the end panel proposed in EC3 is shown in Figure 2. Simultaneity occurrence of the maximum chord forces $N_{c h ; E d}$ and the maximum shear force $V_{E d}$ is assumed.

\subsection{Numerical model with equivalent horizontal load}

In the literature, it was proposed to implement imperfections to the beam model using the horizontal equivalent force, as for example by Falborski et al. (2019). The uniform linear load to one chord along its entire length is applied. The force is calculated so that the bending moment in the center of the column is equal to the moment that would occur in the column with the initial imperfection $e_{0}=L / 500$.

The value of the equivalent horizontal forces can be obtained from the condition of the equilibrium moments:

$$
q=8 \frac{N_{E d} e_{0}}{L^{2}}
$$

The beam model with an additional element redistributing the force from the support to the column was made in the ARSA program. Each pair of battens was modeled as a single beam with a thickness equal to twice the thickness of the batten. All member connections are fixed. The calculations as a nonlinear static analysis were performed.

\subsection{Numerical model with geometric imperfection directly implemented in form of initial bow}

The ARSA program enables implementing the initial imperfection to the model by importing the buckling mode with a specified maximum displacement. A linear buckling analysis was carried out with the beam model from the previous point, and then, using the buckling 


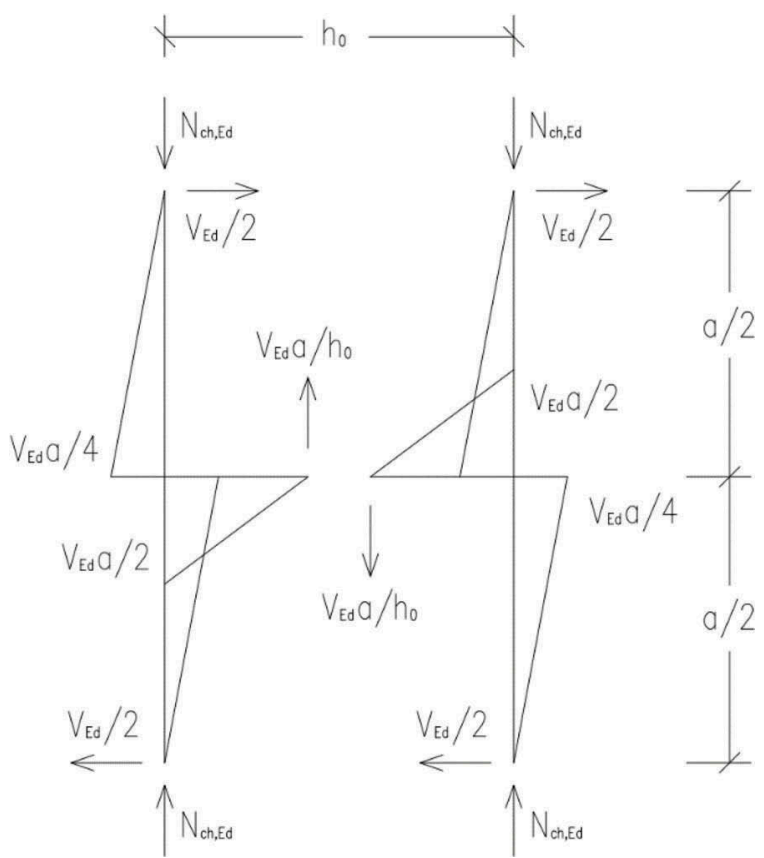

Figure 2. Moments and forces in an end panel of a battened built-up member (EN 1993-1-1 1992).

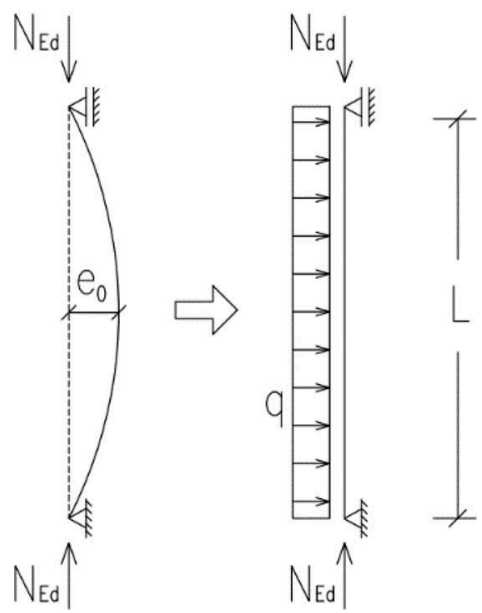

Figure 3. Replacement of initial imperfections by equivalent horizontal forces (EN 1993-1-1 1992).

deformation option, the initial deformation from the first buckling mode was assigned to the model (global buckling of the entire column with a buckling length equal to the column length).

\subsection{Comparison of internal forces}

The comparison of internal forces obtained by different methods is shown in Table 1. Comparing the obtained forces, it can be seen that the normal force in the chord $N_{c h \text {; Ed }}$ is almost 
Table 1. Comparison of internal forces obtained by different methods.

\begin{tabular}{|c|c|c|c|c|}
\hline & $N_{c h, E D}$ & $M_{c h, E D}$ & $V_{b, E d}$ & $M_{b, E D}$ \\
\hline Internal force & {$[\mathrm{kN}]$} & {$[\mathrm{kNm}]$} & {$[\mathrm{kN}]$} & {$[\mathrm{kNm}]$} \\
\hline EC3 procedure & 834.1 & 3.50 & 56.0 & 7.00 \\
\hline Horizontal equivalent load & 832.2 & 3.61 & 38.8 & 4.85 \\
\hline Imperfection in form of initial bow & 831.2 & 3.16 & 39.1 & 4.89 \\
\hline
\end{tabular}

identical regardless of the calculation method used. The results obtained from both numerical methods are very similar. The greater bending moment in the chord $M_{c h \text {; Ed }}$, occurring in the method using the equivalent load, is due to the way the load is applied, which directly increases the bending moment in the chord.

Code calculations assume that the moments on both sides of the chord connected to the batten are equal, therefore the moment in the batten is twice the maximum moment in the chord. However, the maximum moment in the chord occurs only at its end, where it is transferred to the last batten without doubling. The moment on both sides of the chord is summed up on the penultimate batten, at this point the moment in the chord is less than the maximum.

\section{CALCULATION OF THE LOAD CAPACITY}

By knowing the internal forces in the individual elements, it is possible to calculate the load bearing capacity of the entire column using the procedure according to EC3. The PNB-03200:1990 (PN) standard also presents a method of calculating the buckling resistance of built-up columns. The calculation procedure is based on reduction factors.

\subsection{Method of calculating the bearing capacity based on the linear buckling analysis (LBA)}

Method of calculating the bearing capacity based on the buckling resistance procedure of a homogeneous member according to EC3 is proposed. The elastic critical force of the entire column was calculated by the linear buckling analysis in the ARSA program. The buckling curve c was assumed. Similar considerations are described in the article Uziak \& Gizejowski (2010).

\subsection{Comparison with experimental results known from the literature}

For the purpose of comparison of the above-mentioned methods of calculating the resistance of built-up pin-ended columns with battens, the experimental studies carried out by Mitsui \& Sato (2017) were used. The article describes the experimental research, numerical calculations and code calculations according to Design Standard for Steel Structure (AIJ 2005).

In the article the calculations were carried out for columns composed of two cold-formed chords and battens made of flat bars. The connection between them was made by pretension bolts, for the purposes of subsequent calculations, it was assumed that these connections are fixed. Parameters selected to determine the configuration of the specimens were the separation between connectors $a$, the distance between the centroids of chords $h$, and the length of the member $L$. An example of the column cross-section used in the article is shown in Figure 4. In this article, six types of columns each with a height of $L=3700 \mathrm{~mm}$ were used for calculations.

The comparison of load capacities obtained by different methods is shown in Table 2. In most cases, the calculated load capacity is less than that known from the experiments. For built-up members with a small number of battens (a1200h50, a1200h70) the load capacity is significantly underestimated by EC3 and PN code procedures. The load capacities obtained using the LBA method are in most cases more similar to the experimental ones than those 

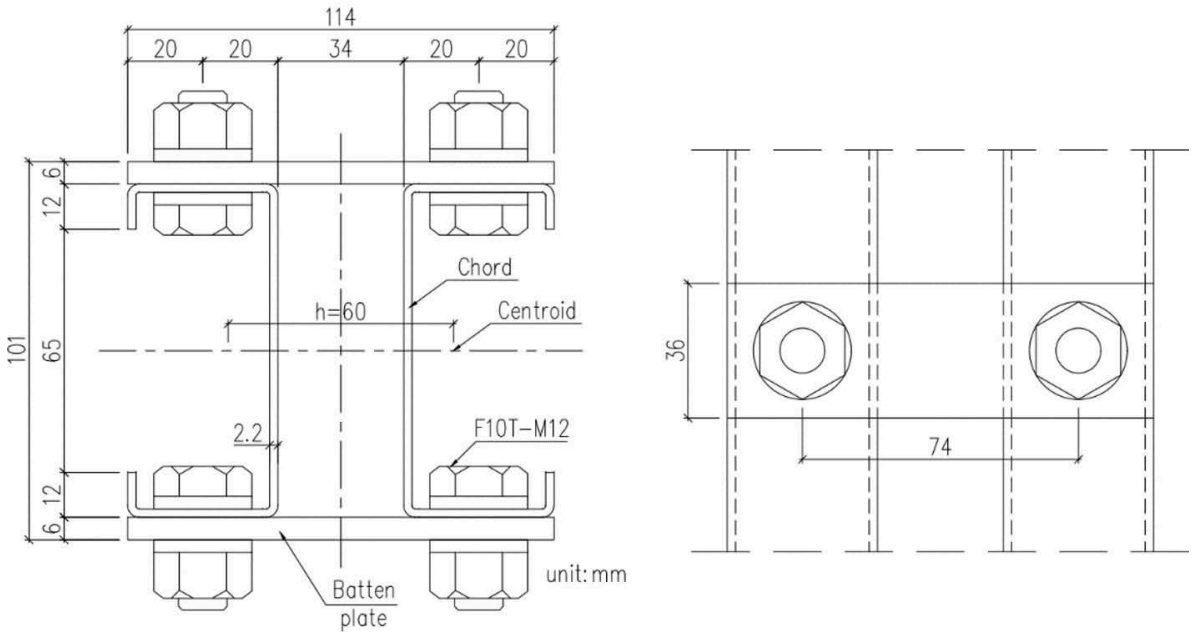

Figure 4. The cross-section of the exemplary column based on Mitsui \& Sato (2017).

Table 2. Load capacities of the tested columns obtained by various methods.

\begin{tabular}{|c|c|c|c|c|c|c|}
\hline & a400h60 & a $720 h 50$ & a $720 h 60$ & a $1200 \mathrm{~h} 50$ & a1200h60 & a $1200 \mathrm{~h} 70$ \\
\hline Method & {$[\mathrm{kN}]$} & {$[\mathrm{kN}]$} & {$[\mathrm{kN}]$} & {$[\mathrm{kN}]$} & {$[\mathrm{kN}]$} & {$[\mathrm{kN}]$} \\
\hline Strength tests (average) & 99.5 & 66.1 & 77.7 & 53.7 & 71.2 & 88.3 \\
\hline EC3 procedure & 92.2 & 60.3 & 79.2 & 46.9 & 57.7 & 65.8 \\
\hline $\mathrm{PN}$ procedure & 81.5 & 59.6 & 73.4 & 49.0 & 58.2 & 66.8 \\
\hline LBA method & 83.8 & 64.4 & 77.7 & 56.9 & 66.5 & 74.7 \\
\hline
\end{tabular}

calculated using the EC3 and PN code procedures. This may indicate that the LBA method describes the resistance of built-up members with battens whose failure model is global buckling, sufficiently well.

\section{CALCULATIONS ON THE SHELL MODEL}

\subsection{Numerical analysis model}

In order to verify the correctness of the critical force calculation on the beam model in ARSA program and to perform geometrically and materially non-linear static analysis, a shell model of the entire column was created in the ABAQUS program. The model was made of a720h60 column, for which the load capacity tested experimentally was $77.7 \mathrm{kN}$. Chords and battens were modeled as shells, the connections between them are fixed. The steel properties were assumed as elasto-plastic according to the data given in the article: yield stress $f_{y}=306 \mathrm{MPa}$, ultimate tensile strength $f_{u}=450 \mathrm{MPa}$, elastic modulus $E=205 \mathrm{GPa}$ and Poisson's ratio $v=0.3$. The column was loaded with a concentrated force at one end.

\subsection{Linear buckling analysis}

In order to obtain critical loads and buckling modes, the linear buckling analysis of the column was performed. The obtained critical force was similar to that obtained from calculations on the beam model. This confirms the validity of using the beam model for the calculations presented earlier. 


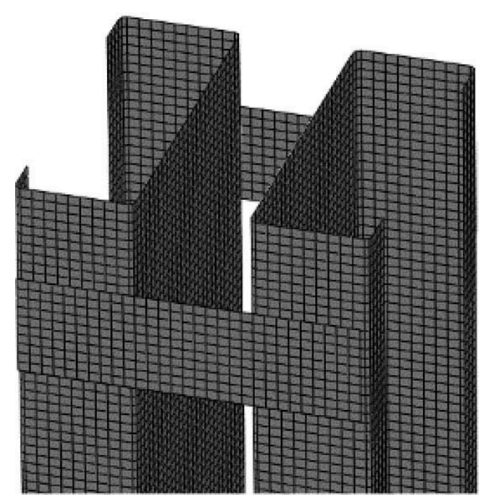

Figure 5. The shell model in the ABAQUS program.

\subsection{Geometrically and materially non-linear static analysis}

Geometrically and materially non-linear static analyses were performed on the presented shell model. The initial imperfection in form of the first buckling mode (similar to bow) of the entire column was assigned to the model, according to the EC3: $e_{0}=L / 500$. Imperfections were assigned by importing nodal displacements from the linear buckling analysis with a set maximum displacement. In the case of the global imperfection assigned only (recommended for built-up members), the obtained load capacity is significantly overestimated and amounts to $86.8 \mathrm{kN}$.

To obtain a result more similar to the strength tests, an additional imperfection related to the buckling of the chord in its central part (buckling between battens) should be added. The bow imperfection (with distortion of the cross-section) with a value of $a / 200$ was introduced. The load capacity obtained in this case was $78.6 \mathrm{kN}$.

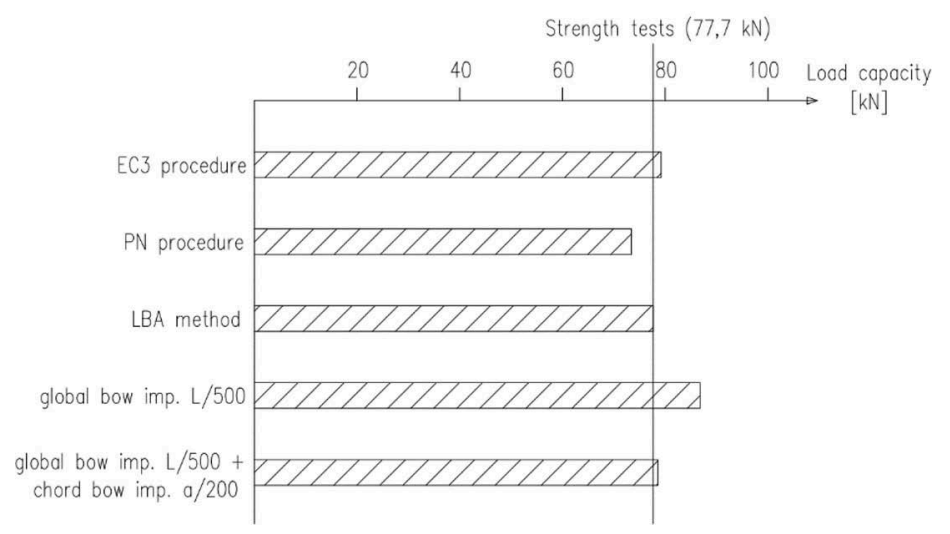

Figure 6. Load capacities of the a720h60 column obtained by various methods.

\section{CONCLUSIONS}

- The code procedure for single homogeneous axially compressed members (LBA) can be used to calculate the global buckling resistance of a built-up column. The buckling curve that best describes the buckling resistance of a built-up member: $\mathrm{c}$. 
- Currently, computer programs allow to perform non-linear static analyses of the entire column model (beam or shell), and the code regulations should specify exactly the imperfections that should be assumed in the model.

\section{ACKNOWLEDGEMENTS}

The numerical calculations were performed using the computing resources of CI TASK at Gdańsk University of Technology.

\section{REFERENCES}

Abaqus, Theory Manual. 2008. Version 6.8. Hibbit, Karlsson \& Sorensen Inc.

Autodesk Robot Structural Analysis Professional - Verification Manual for EU Codes. 2014.

EN 1993-1-1. 2005. Eurocode 3: Design of Steel Structures. Part 1.1: General rules and rules for buildings. Brussels: CEN.

Falborski, T. Knabe, W. Perliński, A. \& Urbańska-Galewska, E. 2019. Wybrane zagadnienia projektowania stalowych konstrukcji prętowych z wykorzystaniem programu Autodesk Robot Structural Analysis. Gdańsk: Wydawnictwo Politechniki Gdańskiej.

Giżejowski, M. Król, P. \& Ślęczka, L. 2008. Projektowanie elementów rozciaganych i ściskanych osiowo wedhug PN-EN 1993-1-1i PN-EN 1993-1-5. Inżynieria i Budownictwo 3/2008: 126-134.

Goczek, J. Supeł, Ł. \& Gajdzicki, M. 2010. Przykłady obliczeń konstrukcji stalowych, Łódź: Wydawnictwo Politechniki Łódzkiej.

Matysiak, A. \& Grochowska, E. 2014. Konstrukcje stalowe ze stupami dwugatęziowymi z przewiązkami projektowane wg norm PN i EN. Przegląd budowlany 9/2014: 41-45.

Mitsui, K. \& Sato, A. 2017. Flexural Elastic Buckling Stress of Batten Type Light Gauge Built-Up Member. Civil and Environmental Engineering Reports No. 25(2): 161-172.

PN-B-03200:1990 Konstrukcje stalowe. Obliczenia statyczne i projektowanie.

Uziak, J. \& Gizejowski, M. 2010. Coupled buckling design of steel laced columns. Botswana Journal of Technology. 18. 10.4314/bjt.v18i2.52261. 